\title{
Między starym i nowym. O sposobach modernizowania przestrzeni publicznych
}

\begin{abstract}
Streszczenie
Głównym celem artykułu jest przedstawienie kilku ważniejszych wzorów modernizacji, jakiej podlegała przestrzeń miejska w Warszawie po 1989 r., ze szczególnym uwzględnieniem różnych sposobów traktowania w III Rzeczypospolitej obiektów typowych dla późnego modernizmu, zwanego też socmodernizmem. Rozważania nawiązują do wyodrębnianych na gruncie instytucjonalizmu historycznego czterech typów zmiany społecznej: przetrwanie i powrót, reprodukcja przez adaptację, stopniowa transformacja, rozpad i zastąpienie. Autor ze swojej strony wyróżnia cztery generalne i siedem bardziej szczegółowych opcji modernizacyjnych oraz pokazuje ich różne urbanistyczno-architektoniczne ilustracje, obecne w warszawskiej przestrzeni publicznej.
\end{abstract}

Słowa kluczowe: przestrzeń publiczna, modernizacja, socmodernizm, polityka miejska

\section{Between the old and the new. Methods of modernizing the public space}

\begin{abstract}
The main aim of the article is to present several of the most important patterns of modernization of the urban space in Warsaw in the post-1989 period, with particular emphasis on the different ways of treating the objects typical of late modernism, also called socmodernism, in the Third Reich. The reflections refer to the four types of social change identified in the context of historical institutionalism: survival and return; reproduction by adaptation; gradual transformation; breakdown and replacement. The author for his part distinguishes four general and seven more specific modernization options and shows their different urban-architectural examples, being present in Warsaw public space.
\end{abstract}

Keywords: public space, modernization, socmodernism, urban policy 
W wielu państwach świata, niezależnie od poziomu rozwoju gospodarczego i uwarunkowań kulturowych, od jakiegoś czasu obserwuje się symptomy ograniczania, dewastowania, dehumanizowania, kryzysu i regresu, wręcz dziczenia przestrzeni publicznych. Tej erozji i degradacji sprzyja lekceważenie urbanistyki oraz zaniedbywanie planowania przestrzennego, niedostatek spójnych i długofalowych wizji rozwoju miast - generalnie osadnictwa. Wyrazem tej tendencji jest chociażby niekontrolowana suburbanizacja, czyli dywanowe rozlewanie się miast na najbliższe otoczenie, co w praktyce jest tożsame ze zbyt rozrzutnym gospodarowaniem przestrzenią, a więc taką polityką, która generuje rozliczne kłopoty, w tym duże i zbędne koszty publiczne.

Jedną z głównych przyczyn pogarszającej się kondycji przestrzeni publicznych był i wciąż pozostaje silny i powszechny trend merkantylny, dążenie do komercjalizacji i prywatyzowania różnych obszarów życia społecznego. Silna presja ekspansywnego rynku i jego mechanizmów, wszechobecne w ostatnich trzech-czterech dekadach tendencje do ekonomizacji i indywidualizacji osłabiały myślenie oraz działanie w kategoriach wspólnoty, nie sprzyjały uwzględnianiu potrzeb i interesów zbiorowych w procesach kreowania czy zarządzania także przestrzeniami publicznymi. Nierzadko przekonujemy się, że np. przestrzenią miejską rządzą przede wszystkim pieniądze, filozofia czysto rynkowa, wąsko pojmowana ekonomia. Negowane i odrzucane bywa wspólnotowe, długofalowe i całościowe spojrzenie na rozwój metropolii, z punktu widzenia szerszych potrzeb ogółu mieszkańców. Świadectwem tego jest widoczna w wielu rejonach miast gentryfikacja, zamieranie troski o równy dostęp wszystkich do dóbr wspólnych, skłonność do grodzenia i odgradzania się od najbliższego otoczenia itp. ${ }^{1}$.

Wskazane procesy nie omijają w szczególności Polski, w której po 1989 r., w ślad za restytucją demokracji i kapitalizmu, postępowały gwałtowna liberalizacja i urynkowienie wielu różnych sfer $^{2}$. Nie bez racji można było mówić w tym kontekście o fali neofickiej fascynacji i o swoistym zachłyśnięciu się rynkiem, zauroczeniu jego mechanizmami. Bezgranicznie, często naiwnie i ślepo, wierzono w ich automatyzm i niezawodność, absolutyzowano je, umacniając przy okazji ogólne przekonanie o wyższości tego, co prywatne, nad tym, co społeczne - miejskie, komunalne, spółdzielcze, publiczne czy państwowe. Znajdowało to wyraz także w nowym kształcie i zasięgu przestrzeni publicznych występujących w polskich miastach.

1 Współczesne tendencje projektowe w kształtowaniu miejskiej przestrzeni publicznej, a także jej główne funkcje i formy, syntetycznie omawia D. Wantuch-Matla, Przestrzeń publiczna 2.0. Miasto u progu XXI wieku, Łódź 2016.

2 Pisałem ostatnio na ten temat w artykułach: W. Anioł, Pułapka ekonomizmu. U źródeł dominacji neoliberalnej narracji modernizacyjnej w Polsce, „Przegląd Socjologiczny” 2015, tom LXIV, nr 2; W. Anioł, Wokół urynkowienia usług społecznych, „Polityka Społeczna” 2016, nr 1. 
Ilustratywnym obszarem owych tendencji rozwojowych jest przestrzeń miejska Warszawy, w której w ciągu ostatnich dwóch-trzech dekad dokonywały się istotne zmiany, charakterystyczne dla panującego w znacznie szerszej skali „ducha czasu”. Pokazywały one m.in. jak transformacyjny „wiatr historii”, napędzany w niemałym stopniu komercją i pogonią za zyskiem, wymiatał z pejzażu miasta i jego publicznych przestrzeni ważne elementy odziedziczonej z przeszłości substancji urbanistyczno-architektonicznej. Spuścizna ta, ze względu na ogrom wojennych zniszczeń miasta mająca głównie PRL-owski rodowód - a więc niejako „źle urodzona”, żeby przywołać tu tytuł znanego zbioru reportaży F. Springera ${ }^{4}$ - była też w mniej lub bardziej zasadniczy sposób modyfikowana.

Głównym celem niniejszego artykułu jest pokazanie kilku ważniejszych wzorów modernizacji, jakiej podlegała warszawska przestrzeń miejska po 1989 r., ze szczególnym uwzględnieniem różnych losów i sposobów traktowania w III Rzeczypospolitej obiektów typowych dla późnego modernizmu, zwanego też socmodernizmem. Warto w tej perspektywie i na podstawie tego konkretnego materiału empirycznego przyjrzeć się bliżej procesom mieszania się w przestrzeni publicznej tego, co stare, z tym, co nowe. A więc swoistej grze, zawieszeniu i rozdarciu między przeszłością, teraźniejszością i przyszłością. Znamiennym napięciom między ciągłością i zmianą. Specyficznemu miksowi tradycji i nowoczesności.

Jak wygląda stare w nowej odsłonie? Jak świeże rozwiązania odnajdują się i załamują w historycznym kontekście? Czy w odnawianych, rekonstruowanych bądź przebudowywanych fragmentach warszawskiej przestrzeni publicznej dostrzec można jakąś spójność i harmonię, czy też może raczej bardziej tam widać wyraźne pęknięcia i szwy? W szczególności, czy warto było ratować i pieczołowicie odnawiać najciekawsze obiekty socmodernistyczne z lat 60.? Czy należało je otoczyć stosowną, bardziej restrykcyjną ochroną konserwatorską, zanim niektóre z nich padły w nowym ustroju łupem ekspansywnych inwestorów rynkowych? Jak więc w praktyce przebiegały na gruncie warszawskim procesy modernizowania architektonicznych dzieł modernizmu? To tylko niektóre z pytań, stawianych tu z intencją poszukiwania nań odpowiedzi.

Niezależnie od głównej uwagi poświęconej perypetiom, jakich doświadczyły po 1989 r. wybrane dzieła późnego modernizmu, w pierwszej części artykułu mowa jest o tuż powojennym okresie odbudowy Warszawy, na podstawie przede wszystkim modernistycznych wzorów, tylko w stosunkowo krótkim okresie zakłóconych

3 Szerzej o tendencjach do urynkowienia i komercjalizacji, deficycie strategicznego planowania, ruderyzacji i segregacji warszawskiej przestrzeni zob. W. Anioł, Kształtowanie przestrzeni miejskiej jak mikrokosmos polityki publicznej. Przypadek Warszawy, „Studia z Polityki Publicznej” 2016, nr 2.

4 F. Springer, Źle urodzone. Reportaże o architekturze PRL, Kraków 2012. 
socrealistycznymi naleciałościami. Zanim jednak przejdziemy do empirycznych wątków i przykładów, spróbujmy najpierw określić kilka modelowych sposobów podejścia do spuścizny instytucjonalnej, ale i - na zasadzie pewnej paraleli czy analogii - budowlanej, jakie znajdują zastosowanie tak w symbolicznie, jak i dosłownie rozumianej przestrzeni publicznej. Nazwijmy i zdefiniujmy niektóre podstawowe koncepcje, wedle których przemeblowywany bywa, z jednej strony - zastany instytucjonalny porządek społeczny, a z drugiej - fizyczny ład przestrzenny.

\section{Jak zmieniać instytucje i przestrzeń publiczną? Kilka typów modernizacji}

Procesy modernizacyjne w ogóle, a zmiany instytucjonalne w szczególności, w zależności od tego, ile w nich elementów zrywających z przeszłością, a ile trwałości i ciągłości, przybierają różne formy. W jednym z ujęć lokujących się w nurcie instytucjonalizmu historycznego, wyróżniono cztery podstawowe rodzaje takiej sytuacji:

1) przetrwanie i powrót (survival and return),

2) reprodukcja przez adaptację (reproduction by adaptation),

3) stopniowa transformacja (gradual transformation),

4) rozpad i zastąpienie (breakdown and replacement) $)^{5}$.

Podczas gdy w dwóch pierwszych wzorach jest więcej kontynuacji, to w dwóch następnych modelach więcej zmiany. W nowych warunkach można podtrzymać swoje istnienie albo w prawie niezmienionej dotychczasowej postaci (wariant 1.), albo stopniowo dostosowując się do czynników zewnętrznych (wariant 2.). Możliwe są też powolne przekształcenia instytucji, np. w drodze dryfu, hybrydyzacji czy konwersji (wariant 3.), a z drugiej strony ich gwałtowny zanik i zastąpienie przez inne, nowe struktury (wariant 4.).

Podobnie jak instytucje, na wiele różnych sposobów można też zmieniać (lub nie zmieniać) szeroko rozumiane systemy społeczne - w tym ustroje polityczne i gospodarcze, tożsamości kulturowe i cywilizacyjne, ale i politykę publiczną. Z drugiej strony, procesy te pod wieloma względami przypominają różnorodność, istotę i dynamikę zmian w substancji urbanistycznej, architektonicznej i budowlanej.

Wielu neoinstytucjonalistów opisuje zniuansowane scenariusze przemian społecznych, ekonomicznych i politycznych przy pomocy takich pojęć jak: porzucanie

5 W. Streeck, K. Thelen, Introduction: Institutional Change in Advanced Political Economies, w: Beyond Continuity: Institutional Change in Advanced Political Economies, red. W. Streeck, K. Thelen, Oxford-New York 2005, s. 8-9. 
szlaku rozwojowego (path-breaking), odchodzenie od niego (path-departing), modyfikowanie lub zmienianie go (path-shifting), a wreszcie tworzenie nowej ścieżki rozwoju (path-creating), niezależnie od definiowania relacji silnej inercji i zależności od dotychczasowego szlaku (path-dependence). Wszystkie te scenariusze, jak również wspomniane wcześniej cztery warianty przeobrażeń instytucji, mogą moim zdaniem znaleźć zastosowanie do analizy przekształceń także przestrzeni publicznych. Podobnie jak w wypadku modernizacji struktur społecznych, gospodarczych i politycznych, zmian zachodzących w obrębie tożsamości kulturowych czy narodowych, również tutaj elementy nowe, innowacyjne najczęściej współistnieją, mieszają się - w bardzo różnorodnych i dynamicznie zmieniających się proporcjach i konfiguracjach - z elementami starymi, pierwiastkami tradycjonalistycznymi.

Weźmy prosty przykład remontu domu. Remont budowlany można potraktować jako metaforę zmiany systemu społecznego, tak jak społeczeństwo i państwo bywają nierzadko alegorycznie nazywane „naszym wspólnym domem”, co w konkretnych uwarunkowaniach i wydaniu skandynawskim znalazło wyraz w politycznej formule Domu Ludu (Folkhemmet) ${ }^{6}$. Remont budynku - równie dobrze jak reforma gospodarki czy polityki społecznej - może być generalny lub tylko kosmetyczny, czyli sprowadzać się jedynie do malowania elewacji, face-liftingu lub make-upu, pacykowania wyłącznie fasady. Remonty zabytkowych obiektów mogą być zachowawcze (wtedy zostawia się np. stare ściany i sklepienia) lub odtworzeniowe, gdy zakłada się i przewiduje rekonstrukcję pewnych elementów po ich ewentualnym wyburzeniu. W jednej z opcji modernizacyjnych oryginalne konstrukcje i detale wyraźnie oddziela się od tego, co nowe i dodane, i co powinno mieć maksymalnie uproszczony kształt, by nie odwracać uwagi od zabytku. W innym zaś wariancie ściślej łączy się stare z nowym, praktykując rozmaite stylizacje i pastisze.

W tym kontekście można dostrzec wiele nie tylko symbolicznych zbieżności i podobieństw do procesów społecznych, wysiłków modernizacyjnych podejmowanych w skali państwa czy regionu, polityki publicznej. Tu i tam występuje szeroka paleta rozwiązań i koncepcji określających zakres, głębokość i tempo zmian. Rozmaite modele i strategie rozwojowe zarysowują perspektywiczne cele i zadania do wykonania, ale wyznaczają też stosunek do przeszłości, zastanych instytucji i reguł gry, tradycji, np. do polskości; kształtują na swój sposób politykę tożsamościową i historyczną.

6 W. Anioł, Szlak Norden. Modernizacja po skandynawsku, Warszawa 2013 (zob. zwłaszcza rozdział VII pt. Dom Ludu po renowacji).

7 Taką doktrynę przy rozbudowie zabytkowych gmachów w Warszawie stosowała była stołeczna konserwator zabytków E. Nekanda-Trepka, czego znamienną ilustracją może być np. nadbudowa piętra w gmachu Hotelu Europejskiego. Zob. M. Wojtczuk, Jak pogodzić stare z nowym, „Gazeta Wyborcza”, 17.01.2016. 
Mówi się na przykład o zbyt naskórkowej, powierzchownej modernizacji, której wyrazem w sensie dosłownym, ale i symbolicznym mogłaby być kostka bauma lub mniej „kosmopolityczny”, swojski polbruk, jakimi w ramach rewitalizacji przestrzeni publicznych powszechnie wykładana jest od jakiegoś czasu nawierzchnia rynków i deptaków w polskich miastach i miasteczkach. Wprawdzie pojawia się tam nowy bruk (niestety, często w miejsce zlikwidowanych skwerów), nowy pastelowy tynk na siedzibie ratusza, są ławeczki i podświetlana wieczorami wszystkimi kolorami tęczy fontanna, ale na zapleczu rynku rozciąga się już często dużo mniej zadbana przestrzeń: łuszczy się farba na elewacjach sfatygowanych kamienic, odpadają tynki, kruszeją gzymsy i balkony, straszą zabite deskami witryny sklepików, w zalatujących moczem bramach degustują tanie wino młodzi bezrobotni albo podstarzali menele. Jeszcze dalej rozciągają się jakieś rudery, powalone płoty i zaśmiecone podwórza. Taka niepełna, fasadowa modernizacja działa zwykle jak plaster na ropiejącą ranę ${ }^{8}$.

Wracając do metafory remontu domu i używając języka architektury i urbanistyki, w podejściu do procesów modernizacyjnych zarysowują się i są możliwe, najogólniej mówiąc, następujące sytuacje do wyboru: 1) konserwacja, 2) restauracja, 3) rewolucyjne zastąpienie, 4) ewolucyjna, hybrydowa transformacja. Objaśnijmy po kolei w skrócie te cztery główne koncepcje.

- Koncepcja konserwacji - „ma być tak, jak jest teraz”

Główne założenie tradycyjnej, można by rzec ortodoksyjnej doktryny konserwatorskiej mówi, że najważniejsza jest stara, autentyczna substancja, trzeba ją więc zachować w aktualnym, obecnym, inaczej mówiąc naturalnym stanie. Nie wolno w niej niczego ruszać czy jej naruszać, nawet jeśli mamy do czynienia z czymś uszkodzonym, częściowo lub - w sytuacji skrajnej - wręcz w całości zniszczonym. W wersji ekstremalnej koncepcja ta zatem głosi, że ruina powinna pozostać ruiną.

Ilustracją takiego podejścia mógłby być jeden z tuż powojennych pomysłów, aby zburzonej Warszawy nie odbudowywać, lecz pozostawić ją w gruzach. Ogrodzone i odwiedzane przez gości ze świata, mogłyby one zaświadczać o skali barbarzyństwa, być moralnym symbolem siły niewyobrażalnej destrukcji. Takie zachowanie ruin jako swoistego zabytku i pomnika wojny proponował publicznie m.in. Kazimierz Wyka. W praktyce zanegowali tę ideę powracający do miasta i pragnący ponownie w nim zamieszkać warszawiacy; tym samym przy pomocy „głosowania nogami” zarzucony został rozważany wcześniej pomysł przeniesienia stolicy Polski do Łodzi.

8 Ciekawą reporterską relację z „miast wyjałowionych”, byłych stolic województw na polskiej prowincji, przedstawił niedawno F. Springer,Miasto Archipelag. Polska mniejszych miast, Kraków 2016. 
W sytuacji, gdy stary obiekt zachował się w wersji pierwotnej, twarda doktryna konserwatorska zaleca, by w imię wierności oryginałowi konserwować nawet jego funkcjonalne defekty czy wady techniczne, co bywa mało komfortowe, dotkliwe i kosztowne, np. gdy przeszklony budynek latem nieznośnie przegrzewa się, a zimą ponadstandardowo wyziębia.

- Koncepcja restauracji - „ma być tak, jak było w przeszłości”

Zakłada ona staranną, wierną pierwowzorowi renowację starego obiektu, względnie nawet rekonstrukcję dawnej przestrzeni w wypadku, gdy przestała ona istnieć. W wersji łagodnej, bardziej umiarkowanej mówi, że trzeba z wielką troską i ostrożnie pielęgnować zabytki, dbać o oryginalną formę urbanistyczno-architektonicznych dzieł, zaś w scenariuszu bardziej radykalnym czy brutalnym postuluje przywracanie do życia nieistniejących już budowli, nawet po wielu latach od ich zniszczenia. W tym drugim wypadku stare kształty bywają odtwarzane $\mathrm{z}$ wielką precyzją, powstają repliki, doskonalsze technicznie kopie ze zrozumiałymi odchyleniami od pierwowzoru, bo wymuszanymi np. zastosowaniem nowocześniejszych technologii. W opinii krytyków takich rekonstrukcji, ich produktem bywa jednak często atrapa, makieta czy falsyfikat, zaś charakter podobnych przedsięwzięć przypomina trochę zabawę w modelarstwo.

Tuż po 1945 r. głównym zwolennikiem koncepcji restauracji w Warszawie był Jan Zachwatowicz, który opowiadał się za odtworzeniem większości miasta w takiej postaci, w jakiej istniało przed wojną. Idea ta zmaterializowała się tylko częściowo, wyspowo i fragmentarycznie, czego pierwszym świadectwem była zrekonstruowana warszawska Starówka, Krakowskie Przedmieście i Nowy Świat. Dopiero potem odbudowano np. Teatr Wielki, w latach 70. zamki Królewski oraz Ujazdowski, a jeszcze później np. Pałac Jabłonowskich - dawny ratusz przy pl. Teatralnym. Przy okazji tej ostatniej inwestycji, podobnie zresztą jak i poprzednich, w sposób nieunikniony pojawiało się jednak pytanie, czy to jest jeszcze ten sam budynek, który istniał przed wojną, czy już tylko jakiś ersatz?

Rekonstrukcja Starego Miasta z ekonomicznego punktu widzenia z pewnością w ogóle się nie broniła, ale przeważyły w tym wypadku zupełnie inne argumenty i racje. Można też z dużą dozą prawdopodobieństwa stwierdzić, że w kraju klasycznej gospodarki kapitalistycznej czy wolnorynkowej, na dodatek z bardzo restrykcyjnym podejściem do ochrony praw prywatnej własności, odbudowa ta raczej w ogóle by nie nastąpiła, albo nie nastąpiłaby tak szybko.

- Koncepcja rewolucyjnego zastąpienia - „ma być tak, jak chcielibyśmy, aby było” 
Przewiduje ona demontaż starego układu lub konstrukcji i realizację zupełnie nowego projektu, w zgodzie z wyartykułowanymi marzeniami i nakreślonymi bliżej planami. Jest to podejście radykalne, bliskie wymienionej wcześniej czwartej formule zmiany instytucjonalnej, określonej jako „rozpad i zastąpienie”. W przestrzeni miejskiej oznacza to, że można wyburzyć stare budowle (lub usunąć pozostałe po nich gruzy) i zastąpić je (lub nie) całkiem innymi obiektami.

Zaraz po wojnie wpływowa była w Warszawie idea radykalnej odbudowy miasta, $\mathrm{w}$ istocie zaś wzniesienia go od nowa wedle założeń modernistycznych, w duchu Le Corbusiera, ale też w nawiązaniu do dalekosiężnych planów urbanistycznych przedwojennego prezydenta Stefana Starzyńskiego. Ograniczenia finansowe i przaśna doktryna socrealizmu rychło skorygowały te bardzo nowoczesne wizje. Niemniej jednak godzi się przypomnieć, że realizacja monumentalnej zabudowy MDM z pl. Konstytucji czy wznoszenie Pałacu Kultury wraz z okalającym go pl. Defilad było związane z wyburzeniem setek spalonych kamienic czynszowych, w większości będących w beznadziejnym stanie technicznym, na dodatek wąskich, z ciemnymi podwórkami studniami, ale także tych prawdopodobnie nadających się do odbudowy, np. wielu ulokowanych na zachodniej pierzei ul. Marszałkowskiej. Również w innych rejonach miasta ocalałą, a nie mieszczącą się w nowym kanonie przedwojenną substancję budowlaną często niszczono, w najlepszym zaś razie ignorowano lub gruntownie przerabiano, m.in. skuwając dekoracje i zdobienia $\mathrm{z}$ fasad zachowanych w znośnym stanie secesyjnych kamienic.

- Koncepcja ewolucyjnej, hybrydowej transformacji - zakłada mieszane eksperymenty modernizacyjne, łączące $\mathrm{w}$ sobie nakazy i postulaty charakterystyczne dla trzech wcześniejszych doktryn: ma być trochę tak, jak jest, częściowo tak, jak było, ale też nieco tak, jak chcielibyśmy, aby było w zupełnie nowej odsłonie, w postaci ani wcześniej, ani obecnie niewystępującej

Możliwe (i zresztą najciekawsze) są zatem w końcu realizowane na ogół stopniowo rozwiązania hybrydalne i synkretyczne, rozmaite sploty tradycji z nowoczesnością, planistyczne i artystyczne fuzje, krzyżówki i mezalianse. To często ryzykowna gra, bo stosując podobne praktyki, można łatwo albo otrzeć się o kakofonię, albo wpaść w chaos, albo wręcz sprzeciwić się poczuciu dobrego gustu i smaku. Nieobecność wyrazistych wizji, klarownych i jednoznacznych strategii zmian, niedostatek głębokich i gwałtownych reform, niechęć do nagłych zwrotów i szokowych terapii - wszystko to często sprzyja bezwolnemu dryfowaniu w nieznanym kierunku.

Patrząc kompleksowo, po II wojnie światowej w Warszawie została wdrożona w gruncie rzeczy mieszana koncepcja urbanistyczno-architektoniczna. W historycznym 
centrum, by utrwalić tożsamość miasta i przekazać ją następnym pokoleniom, nastąpiła rekonstrukcja całej grupy zabytków o randze narodowych symboli. Połączono jednak to przedsięwzięcie z zasadniczą przebudową reszty stolicy opartą na nowych, świeżych pomysłach modernistycznych, a także narzucanych ze Wschodu wzorcach socrealistycznych. Taki wybór wynikał z kilku powodów i przyczyn. Po pierwsze, miał uzasadnienia funkcjonalne, gdyż warto było przy okazji odbudowy wiele poprawić w układzie miejskim, np. udrożnić komunikację, rozluźnić ciasną zabudowę, rozszerzyć tereny zielone. Po drugie, w grę wchodziły tu motywy finansowe, ponieważ całościowa restauracja przedwojennego „Paryża Wschodu” byłaby naturalnie znacznie droższa. Po trzecie wreszcie, $w$ tle podejmowanych decyzji najprawdopodobniej obecne było fundamentalne przekonanie, że urbanistyka i architektura jako sztuki żywe powinny być czułe na zmiany zachodzące w otoczeniu, odzwierciedlać nową epokę, iść do przodu, z duchem czasu, a nie zasklepiać się w starych formach czy kurczowo trzymać się wcześniejszych założeń i planów.

W rezultacie, atutem i siłą współczesnej Warszawy wydają się jej autentyczna różnorodność i wielowarstwowość, przemieszanie różnych prądów architektonicznych, współwystępowanie elementów pochodzących z różnych epok historycznych i konwencji stylistycznych ${ }^{9}$. Przejawy zarówno bardzo wiernej - co najmniej duchowi pierwowzorów, jeśli nie samej ich literze - modernizacji elementów przestrzeni miejskiej, jak i synkretycznego melanżu, dostrzec można również na poziomie pojedynczych obiektów, o czym będzie szerzej mowa w dalszej części tekstu. Doświadczenia te pokazują, że rozwiązania hybrydalne bywają bardzo twórcze, ale niekiedy też dość pokraczne.

Zanim jednak sięgniemy po konkretne ilustracje co ciekawszych przekształceń wybranych dzieł warszawskiego socmodernizmu w okresie po 1989 r., przypomnijmy pokrótce, jak ten specyficzny nurt myślenia o przestrzeni miejskiej koncepcyjnie i realnie usadowił się w stolicy tuż po wojnie. Można by postawić tezę, że o ile brutalne potraktowanie niektórych tych dzieł w wolnorynkowych realiach III Rzeczypospolitej było w jakimś sensie symptomem i świadectwem braku wiary Polaków w ciągłość historyczno-kulturową, o tyle sam modernizm również nie grzeszył nadmiernym szacunkiem do tradycji, albo inaczej mówiąc - uznawaniem prymatu metod ewolucyjnych nad rewolucyjnymi.

\footnotetext{
9 Por. rozmowę z pisarką Beatą Chomątowską, „Gazeta Wyborcza”, 6.03.2017.
} 


\section{Modernizm w powojennej Warszawie}

Le Corbusier - czołowy przedstawiciel modernizmu w urbanistyce i architekturze, nazywany „papieżem” tego kierunku, choć w Polsce nigdy nie był i niczego nie zaprojektował, miał tu wielu współpracowników i naśladowców ${ }^{10}$. W opracowaniu wpływowej Karty Ateńskiej z 1933 r., poniekąd kodyfikującej idee Corbusierowskie, uczestniczył np. Roman Piotrowski, który zaraz po wojnie był szefem Biura Odbudowy Stolicy (BOS), potem zaś ministrem odbudowy i szefem resortu budownictwa. Dokument ten odegrał kluczową rolę w wypracowaniu koncepcji odbudowy Warszawy, całkiem odmiennej od tej, jakiej hołdowali konserwatywni i idealizujący przedwojenny obraz miasta miłośnicy XIX-wiecznych kamienic ${ }^{11}$. Z kolei współautorem Manifestu z Doorn z 1954 r., jednego z ważniejszych dokumentów powojennej urbanistyki, który wzmacniał środowiskowe aspekty powyższej karty - wskazując m.in. na to, iż modernizm międzywojenny cierpiał na nadmierną fascynację formą - był znany polski architekt Oskar Hansen.

Idee Le Corbusiera już przed wojną miały duży wpływ na wielu polskich architektów oraz planistów pracujących nie tylko w warszawskim ratuszu, gdzie współtworzono kształt takich osiedli jak Żoliborz czy Saska Kępa. Świetne przykłady awangardowej modernistycznej architektury odnajdziemy też w międzywojennych dzielnicach Gdyni czy Katowic. Ale dopiero po wojnie, w prawie kompletnie zburzonej Warszawie, idee te trafily na wyjątkowo podatny grunt. Fizyczne zniszczenia substancji miejskiej i wywłaszczeniowy, likwidujący prywatną własność gruntów dekret Bieruta z 1945 r., przyjęty zresztą z inicjatywy BOS, „oczyściły” teren i pozwoliły projektować i szybko odbudowywać całe miasto niemal od podstaw. Autorytarny, a już wkrótce potem totalitarny ustrój, paradoksalnie, ułatwiał forsowanie i realizację śmiałych, pełnych rozmachu planów. Odważnych i radykalnych posunięć władzy nie krępowały bowiem reguły praworządności, wolnego rynku czy demokracji, w której obywatele mają swoje niezbywalne prawa (w tym własnościowe), mogą na coś się nie zgadzać i protestować, wymagają konsultowania ze sobą różnych decyzji itd.

Licencjonowani przez władzę urbaniści, architekci i inżynierowie, których większość była przedwojennymi modernistami, uzyskali zatem ogromne pole do popisu, mogąc realizować swoje wizje niejako ponad głowami mieszkańców. Zagłada miasta okazała się wielką twórczą szansą dla zaangażowanych w jego odbudowę

$10 \mathrm{Z}$ ponad 50 książek, jakie napisał w życiu, dwie wydają się najważniejsze: Le Corbusier, W strone architektury, Warszawa 2012; Le Corbusier, Urbanistyka, Warszawa 2015.

11 Spór o odbudowe Warszawy. Od gruzów do reprywatyzacji, red. T. Fudala, Warszawa 2017. 
takich ludzi, jak Maciej Nowicki, twórca Muranowa Bohdan Lachert, Józef Sigalin i inni wizjonerzy, marzący o głębokich „interwencjach chirurgicznych” w organizm miasta, rysujący swoje nowatorskie projekty na - jak to lubili powtarzać moderniści - czystych, białych kartkach.

Nie przeszkadza to stwierdzić - a co przyznają też liczni, w tym współcześni eksperci - że prowadząc swoje prace, Biuro Odbudowy Stolicy inspirowało się przede wszystkim koncepcją miasta bliskiego potrzebom ludzi, egalitarnego, w istocie demokratycznego, szanującego zasady architektury funkcjonującej społecznie. Niezależnie od wszystkich popełnionych błędów, bylejakości wielu siermiężnych i przaśnych rozwiązań, całkiem zrozumiałych w tamtym czasie technologicznych słabości, odbudowa Warszawy odbywała się w sposób planowy, racjonalny, oszczędny, na swój sposób nowoczesny, z myślą o większej całości. Co ciekawe, jeśli chodzi o styl architektoniczny i założenia urbanistyczne, wiele idei Le Corbusiera było realizowanych przez PRL-owskie władze nawet w najgorszym okresie stalinowskim, tyle że w socrealistycznym kostiumie. Pewną znamienną koncesją ideologiczną na rzecz doktryny ludowych rządów robotniczo-chłopskich było np. „wprowadzanie ludu do śródmieścia”, do monumentalnych socpałaców w stylu Marszałkowskiej Dzielnicy Mieszkaniowej (MDM), co pozostawało w niejakiej sprzeczności z zalecaną przez modernizm prostotą oraz zasadą segregacji miejskich funkcji, w myśl której centrum miasta nie było uznawane za najlepsze miejsce do zamieszkania, zwłaszcza przez większe rodziny, a nowe osiedla sypialnie miały powstawać na oddalonych od niego obrzeżach.

Z kolei dobrym przykładem i przejawem rozsądnego planowania, długofalowej wizji rozwoju aglomeracji o modernistycznym rodowodzie była strategiczna decyzja w sprawie udrożnieniu komunikacji w Warszawie poprzez przecięcie wyburzonego śródmieścia wielopasmowymi arteriami: poszerzoną dwukrotnie Marszałkowską (jako taka miała służyć także propagandowym defiladom) i jej przedłużeniem ul. Nowotki (dziś Andersa), poszerzonymi Al. Jerozolimskimi oraz dwiema nowymi tzw. Trasami: W-Z, czyli ul. Świerczewskiego (dziś Solidarności) oraz N-S, czyli ul. Marchlewskiego (dziś Jana Pawła II). Rozcięcie miasta szerokimi ulicami zlikwidowało wąskie gardła komunikacyjne, a przy okazji pozwoliło rozluźnić zabudowę. Przed wojną stolica była z trudem przejezdna, miała gęstą, poplątaną sieć ulic i jeden z najgorszych w Europie wskaźników gęstości zabudowy i zaludnienia - 10 tys. osób na km kw. (dla porównania obecnie współczynnik ten jest trzykrotnie mniejszy i wynosi ok. 3 tys. na km kw.).

Inną ilustracją modernistycznych inspiracji może być wybudowanie wielu całkowicie nowych osiedli mieszkaniowych, takich jak Muranów, Sady Żoliborskie, Bródno, Ursynów Północny czy Gocław. Za symbol i kwintesencję późnego modernizmu uchodzi wielkie Corbusierowskie osiedle Za Żelazną Bramą, powstałe na przełomie 
lat 60. i 70. XX w. w samym centrum Warszawy, na miejscu porośniętego chwastami wielkiego usypiska gruzów, jakie pozostały po kompletnie zniszczonej dzielnicy żydowskiej. Na osiedle składa się 19 ogromnych, przypominających mamucie szafy 15-piętrowych bloków oraz kilkanaście jednopiętrowych pawilonów usługowych, jak również zorganizowane pod domami zieleńce i place zabaw dla dzieci. Bloki ustawiono elewacjami na wschód i zachód, inaczej niż jest to praktykowane obecnie - w dużej odległości od siebie, rozrzutnie, bez oglądania się na wartość ziemi, aby zapewnić lepsze nasłonecznienie, a mieszkańcy mogli podziwiać dalekie widoki i zieleń za oknem. Zachowane tu bardzo nieliczne zabytki (Hale Mirowskie, synagoga, kościół św. Karola Boromeusza) zostały wyeksponowane - odnowione i „oczyszczone” z zasłaniających je ruder.

W parterach bloków urządzono sklepy, nie tylko spożywcze. Znana duża księgarnia Atlas przetrwała w jednym z nich do dzisiaj, chociaż szkoda, że z dachu tego budynku już dawno temu zniknął charakterystyczny neonowy globus ${ }^{12}$. W dużych przeszkolonych holach, przypominających hotelowe lobby, dla wygody mieszkańców umieszczono kioski Ruchu. Szyku w czasach późnego Gomułki zadawały półautomatyczne windy produkowane na szwedzkiej licencji.

Osiedlowe mieszkania często krytykowano za ograniczony, ,gomułkowski” metraż i słynne ciemne, ślepe kuchnie, z których okienko wychodziło co najwyżej na większy pokój, zwany bardzo przesadnie „salonem”. Małe, ciasne lokale były produktem oszczędnych, restrykcyjnych normatywów - np. czteroosobowa rodzina mogła dostać klucze do mieszkania M-4 o maksymalnej powierzchni 48 mkw., jednopokojowe M-2 miało metraż 27 mkw., a M-3 - 39 mkw. Kiedyś gnieździły się tam całe wielodzietne i często wielopokoleniowe rodziny, ale warto pamiętać, że w PRL dla wielu ludzi już samo mieszkanie w bloku było ogromnym społecznym i życiowym awansem. Obecnie takie mieszkania zajmowane są głównie przez niewielkie rodziny, singli, studentów, osoby starsze, zagranicznych i krajowych migrantów. Wielu współczesnych lokatorów osiedla docenia ekonomiczne i ekologiczne zalety mieszkania w samym centrum miasta, a nie na przedmieściach, co oznacza dla nich większą wygodę, oszczędność czasu, mniej kosztów i emisji spalin związanych z wydłużonymi dojazdami do pracy, zaś w szerszym wymiarze procentuje to mniejszymi obciążeniami dla miejskiej infrastruktury i środowiska, a w konsekwencji także dla zdrowia wszystkich warszawiaków.

Czy zatem osiedle Za Żelazną Bramą dobrze, a nawet coraz lepiej, znosi próbę czasu i „ładnie się starzeje”? Zdania na ten temat są podzielone. Pod wieloma

12 Modernistycznym inwestycjom w Warszawie lat 60. często towarzyszyła „neonizacja”. Pojawiające się na ulicach awangardowe neony były o tyle symboliczne dla PRL, że pod wieloma z nich często nie było co kupić, nawet produktów przez nie reklamowanych. 
względami jest ono dziś po latach chwalone ze wskazanych powyżej i innych jeszcze powodów, m.in. wielu lokatorom podobają się bardziej ergonomiczne niż obecnie praktykowane rozwiązania w mieszkaniach, dobrze służą mieszkańcom osiedla zbudowane tam wcześniej szkoły i przedszkola, rozrósł się chętnie odwiedzany Park Mirowski - oddzielający osiedle od Hali Mirowskiej tam, gdzie przed wojną biegła ul. Krochmalna itd. Z drugiej strony, kontrowersje wzbudza zwłaszcza intensywne w ostatnim okresie zagęszczanie osiedla nowymi biurowcami, redukujące wolne kiedyś przestrzenie, także ze szkodą dla nasłonecznienia mieszkań itp. Znamienne jednak, że obowiązujące kiedyś przepisy o dostępie światła słonecznego do mieszkań przestały w nowych czasach obowiązywać, dlatego także w innych częściach miasta wyniosłe wieżowce mogą już pozbawiać słońca mieszkańców sąsiadujących z nimi bardzo blisko bloków.

Jeszcze więcej zarzutów i pretensji jest kierowanych pod adresem wielu innych modernistycznych blokowisk postawionych z tzw. wielkiej płyty w innych miejscach Warszawy, a także Polski. Mając zaspokajać wielki powojenny głód mieszkaniowy, realizowały one idee Le Corbusiera w wersji jeszcze tańszej, masowej, gorszej, cokolwiek wypaczonej, żeby nie powiedzieć zdegenerowanej i prymitywnej. Postulowana wysoka jakość przeszła w ilość. W praktyce powstawały tysiące małych, niewygodnych lokali z kiepskich materiałów i w marnym, "paździerzowym” standardzie (np. zamiast drewnianych podłóg w pokojach - płytki PCW, małe okna w grubych, nietrzymających ciepła ścianach). Często narzekano na złe wykonawstwo (np. krzywe ściany i sufity, szpary w oknach i pozostałej stolarce), na niedokończone dzielnice bez zieleni i całej społecznej infrastruktury, które to elementy, pierwotnie zaplanowane do realizacji, pozostawały niestety jedynie na deskach kreślarskich projektantów. Te siermiężne, z reguły zaniedbane dziś „,biedabloki”, pospiesznie poskładane z prefabrykatów wyprodukowanych w tzw. fabrykach domów, tylko w niewielkim stopniu przypominają solidny pionierski Blok Marsylski, jaki stworzył Le Corbusier tuż po wojnie. Stanowią symbol raczej nie modernizmu, lecz zgrzebności i bylejakości minionego ustroju, systemu PRL.

Przy czym warto dodać, że sama idea konstrukcji „maszyn do mieszkania” przy pomocy technologii prefabrykowanych bynajmniej nie zdewaluowała się, lecz w różnych częściach świata przetrwała. O czym dowodnie może świadczyć fakt, że w odróżnieniu od Polski jest do dzisiaj bardzo szeroko i z powodzeniem stosowana np. w krajach skandynawskich. I to nie tylko przy wznoszeniu biur czy obiektów użyteczności publicznej, ale i w budownictwie mieszkaniowym. Na przykład w Kopenhadze ogromna większość nowych osiedli powstaje wciąż z wielkiej płyty i innych prefabrykatów, tyle że ich jakość jest coraz wyższa. 


\section{Spuścizna po socmodernizmie: burzyć czy chronić?}

Odnotujmy fakt, że w Polsce na tle i w zderzeniu ze wspomnianą masą byle jakich i sztampowych klocków, mrówkowców i całych blokowisk z wielkiej płyty, w latach 60. zajaśniała w Warszawie swoją oryginalnością cała seria artystycznych perełek późnego modernizmu. Na fali popaździernikowej odwilży w polityce i kulturze dał się zaobserwować $m$.in. powrót do funkcjonalizmu. Powstało wówczas $\mathrm{w}$ stolicy wiele budynków o architekturze wysokiej klasy, otwartej na zachodnie wzory, szczególnie skandynawskie ${ }^{13}$. To były najczęściej niszowe inwestycje w rodzaju pawilonów handlowo-usługowych czy małych dworców kolejowych, które zaznaczyły swoją odrębność, zwłaszcza na tle położonych w niedalekim sąsiedztwie pompatycznych, kapiących od kamiennych dekoracji dzieł socrealizmu, takich jak PKiN czy MDM.

Ów późny modernizm, do którego zaliczane są rzeczone, powstające po $1956 \mathrm{r}$. w Warszawie obiekty inspirowane ideami Le Corbusiera, w wydaniu PRL-owskim bywa nazywany socmodernizmem. Po raz pierwszy tym terminem posłużył się prof. Adam Miłobędzki, jeden z najważniejszych historyków i krytyków polskiej architektury, w swojej książce z początku lat $90 . \mathrm{XX} \mathrm{w}^{14}$. W ten sposób nazwał on styl dominujący w krajowym budownictwie od schyłku lat 50. do końca lat 80. XX w. Neologizm ów był w tym autorskim ujęciu nacechowany raczej negatywnie, jego znaczenie obciążał zwłaszcza przedrostek „soc”.

Co stało się z reliktami architektury późnego modernizmu w Warszawie, jak zostały one potraktowane w najnowszych czasach? Czy uznano je za oryginalne dziedzictwo polskiej kultury, godne zachowania i starannej pielęgnacji? Czy też zwyciężył pogląd, że nie zasługują one na przetrwanie - w ogóle bądź tylko w dawnej, niezmienionej postaci? Skoro nierealne okazywało się to ostatnie, to w jaki sposób przerabiano i adaptowano te obiekty do nowych czasów, trendów stylistycznych, potrzeb i funkcji?

Zanim przyjrzymy się kilku przykładom kontrowersyjnych, bardzo niejednoznacznych rozwiązań zastosowanych w praktyce w tym zakresie, pokażmy najpierw ilustracje dwóch radykalnych, ekstremalnych, krańcowo różnych podejść do odziedziczonych po PRL „perłach modernizmu”. Pierwszą opcją jest odnowienie z pietyzmem i renesans dawnych obiektów, drugą zaś - ich całkowite wyburzenie i postawienie na ich miejscu nowych budynków.

13 Więcej o rozwoju Warszawy w okresie gomułkowskim zob. B. Brzostek, Za progiem. Codzienność w przestrzeni publicznej Warszawy 1955-1970, Warszawa 2007.

14 A. Miłobędzki, Architektura ziem polskich - rozdział europejskiego dziedzictwa, Kraków 1994. 
- Dwa rozwiązania skrajne: odnowa integralna versus totalna destrukcja

Egzemplifikacją pierwszej sytuacji, czyli wiernej i udanej rewitalizacji, jest los dworców kolejowych Ochota, Powiśle i Stadion na linii średnicowej w samym środku Warszawy. Te lekkie, filigranowe i dynamiczne konstrukcje powstały na przełomie lat 50. i 60. XX w., a ich charakterystycznym wspólnym motywem stały się łupinowe dachy $\mathrm{z}$ betonu (przypominające trochę origami) oraz dobrze współgrające z nimi, racjonalnie rozplanowane przeszklenia ${ }^{15}$. Szwajcarski krytyk architektury Werner Huber nazwał je „perłami na torach”. Niestety, przez całe lata niekonserwowane, w końcówce PRL i w pierwszej dekadzie ustrojowej transformacji zostały ogromnie zaniedbane, obrosły liszajami brudu i zacieków; na dodatek w nowym ustroju zastawiono je nachalnymi reklamami i szpetnymi budami gastronomicznymi i handlowymi. Na szczęście, podupadłym dworcom udało się po 2000 r. przywrócić dawny blask, gdy starannie odnowiono elewacje i daszki, wymieniono brudne i potłuczone okna, usunięto z ich otoczenia agresywne reklamy i tandetne stragany. Dawną świetność unikatowym, lecz mocno nadgryzionym przez „ząb czasu”, zapyziałym i zaropiałym przystankom kolejowym rozumnie przywrócił ich właściciel - PKP.

Mniej szczęścia pod tym względem miał powstały w 1961 r. na Woli, dziś przy ul. Solidarności, modernistyczny pawilon baru Wenecja. Wprawdzie wciąż istnieje, ale w 2000 r. został przerobiony na biurowiec, który dziś zajmuje prywatna przychodnia. Niefortunna przeróbka zniekształciła ów obiekt nie do poznania. Całkowicie stracił on swój dawny klimat, który wyznaczały kiedyś duże szklane witryny i nowoczesna elewacja z cegły klinkierowej.

Jeszcze gorszy los spotkał po 1989 r. - i to będzie ilustracja drugiej opcji radykalnej, czyli unicestwienia - kilka pawilonów handlowych, które stanowiły równie cenne jak powyższe dworce, znakomite świadectwo warszawskiego socmodernizmu $\mathrm{z}$ lat 60. XXw. Podobnie delikatne, finezyjne i funkcjonalne, skąpane w świetle, z komercyjnych powodów poszły pod kilof, a w ich miejsce powstały rzeczy nowe. Bodaj najwybitniejszym $\mathrm{z}$ tych uśmierconych obiektów był nowatorski, wręcz genialny w swej konstrukcji, a przy tym piękny w formie sklep spożywczy Supersam przy ul. Puławskiej. Fascynował wszystkich zwłaszcza jego oryginalny dach, wiszący na całej rozpiętości budynku prawie bez podpór. Pawilon powstał w 1962 r., a zniknął w 2006 r., zastąpiony przez otwarty w 2013 r. ogromny kompleks biurowo-handlowy Plac Unii City Shopping z 90-metrowym wieżowcem.

15 O ich dwóch twórcach, projektujących przed wojną także Dworzec Główny, a po wojnie (przez 29 lat!) Dworzec Centralny zob. AR/PS. Architektura Arseniusza Romanowicza i Piotra Szymaniaka, red. G. Piątek, Warszawa 2012. 
Nie więcej szczęścia miał ciekawy, doskonale pasujący do otaczającej przestrzeni pawilon Chemii z 1960 r. na rogu ulic Brackiej i Nowogrodzkiej. Przyciągał uwagę przechodniów z każdej strony, oglądany niemal na przestrzał, dobrze widoczny, bo rozświetlony, także w nocy, niczym UFO. Zastąpiony został w 2008 r. masywnym, czarnym jak węgiel luksusowym domem handlowym Vitkac, który nie tylko zabrał światło mieszkańcom sąsiedniego bloku, ale i przytłoczył swoimi gabarytami i stylistyką całą okoliczną przestrzeń ${ }^{16}$. Podobnie marny los spotkał trzeci ze śródmiejskich pawilonów - mały salon meblowy przy ul. Przeskok, wyburzony pod nowy biurowiec. Lekkość, eteryczność i przejrzystość wszystkich tych modernistycznych brył robiły wrażenie zwłaszcza na tle sąsiadujących z nimi szarych bloków i kamienic. W mediach dominował głos obrońców owych budowli, choć i zwolennikom wyburzeń nie brakowało pewnych argumentów, wskazujących m.in. na ich technologiczne zużycie i mankamenty: wykonanie z marnych, byle jakich materiałów, bardzo słaby standard termiczny, zbliżający się niebezpiecznie do norm spełnianych przez wiaty przystankowe. Przypominano, że np. Supersam zajmował wielką działkę w miejscu, w którym już przed II wojną światową projektowano postawienie wysokościowca itd.

W praktyce najważniejszym motywem zastąpienia dotychczasowych konstrukcji przez nowe inwestycje okazywały się jednak racje finansowe i komercyjne. Towarzyszyły one wyraźnie zniknięciu z przestrzeni Warszawy także kilku interesujących architektonicznie powojennych kin, takich jak Moskwa i Skarpa. Był to rezultat ich pochopnej prywatyzacji, m.in. z udziałem kontrolowanej przez mazowiecki samorząd spółki Max Film, która je przejmowała i która, jak się szybko okazało, nie była w ogóle zainteresowana wyświetlaniem filmów, lecz tylko ubijaniem interesów z deweloperami, którzy na miejscu tych zdemontowanych modernistycznych siedzib kin rychło postawili postmodernistyczne biurowce i apartamentowce (w kompleksie powstałym na miejscu kina Moskwa rozpoczął wprawdzie działalność również multipleks, ale nie przetrwał tam długo). Mniej brutalnie obszedł się nowy właściciel z kinem Praha na prawym brzegu Wisły, które po prywatyzacji znacząco przebudowano, ale którego nie zlikwidowano.

Między pieczołowitym, wiernym i w sumie bardzo udanym odnowieniem odziedziczonych z przeszłości dzieł architektonicznych a ich wyburzeniem rozciąga się szeroka gama różnych podejść i niejednoznacznych wzorów modernizacji. Przedstawimy

16 Filip Springer obrazowo i alegorycznie porównał tę zmianę do zastąpienia świetlistego Skywalkera (pawilon Chemii) przez strasznego i mrocznego lorda Vadera (Vitkac). Uznaje ten nowy dom handlowy za wymowny symbol niekontrolowanego brutalnego kapitalizmu, który całkowicie ignoruje kontekst, wyraża pogardę dla tego, co wokół. Ma artykułować nieliczącą się z niczym siłę, ma być manifestacją drapieżności, wyniosłości i arogancji wynikającej z materialnego statusu i wszechwładzy pieniądza, F. Springer, Księga zachwytów, Warszawa 2016, s. 11, 200. 
poniżej cztery z nich, wraz z konkretnymi ilustracjami. Warianty te można określić następująco: 1) destrukcja w imię odnowy, 2) reinkarnacja, 3) translokacja $z$ metamorfozą, 4) twórczy dialog z przeszłością.

- Destrukcja w imię odnowy - przypadek Cedetu

Spośród dyskusyjnych rekonstrukcji w ścisłym centrum Warszawy wymieńmy najpierw przykład, jak się wydaje, porażki modernizacyjnej. Chodzi o gmach zbudowany w latach 1949-1952 i pierwotnie przeznaczony na siedzibę Centralnego Domu Towarowego (CDT), jako Centralny Dom Dziecka (CDD) ochrzczony następnie - po pożarze i rekonstrukcji w 1975 r. - Smykiem. Był dość powszechnie uważany przez specjalistów za najważniejszy budynek wzniesiony w Warszawie tuż po wojnie. Dzieło Zbigniewa Ichnatowicza i Jerzego Romańskiego było uznawane za wybitny, wręcz podręcznikowy przykład powojennego modernizmu, w istocie najcenniejszy w grupie ówczesnych inwestycji nawiązujących do czystego funkcjonalizmu. Do grupy tej można było zaliczyć osiedle Muranów, dzielnicę urzędową między pl. Trzech Krzyży a Kruczą, Hożą i Żurawią (przypominającą podobne zespoły o wydzielonej funkcji biurowej we Francji czy USA), Grand Hotel przy ul. Kruczej czy nawet Dom Partii, dawną siedzibę KC PZPR, a obecnie całą paletę instytucji kapitałowo-biznesowych (cóż za chichot historii w tej zmianie lokatorów!) przy obecnym rondzie de Gaulle’a.

CDT był pierwszym w centrum miasta prawdziwie „szklanym domem”. Widziano w nim manifest i powiew nowoczesności, postrzegano go trochę tak, jak przed wojną traktowano wieżowiec Prudentialu przy pl. Napoleona. Pewnej ironii czy pikanterii całej sytuacji dodaje fakt, że zrealizowano ten projekt już w czasach panowania doktryny socrealizmu w kulturze i sztuce. Nawiasem mówiąc, wspomnianych architektów zmuszono do złożenia samokrytyki za błędne zachłyśnięcie się kosmopolitycznymi trendami, które tak surowo potępiali wówczas socrealistyczni politrucy i partyjni nadzorcy kultury.

Twórcy CDT dość wiernie zastosowali w projekcie pięć podstawowych zasad architektonicznych Le Corbusiera: 1) dom na słupach, 2) wolny plan, 3) wolna elewacja, 4) pasmowe okna, 5) płaski dach z tarasem. Niektóre z tych elementów naruszono już podczas odbudowy gmachu po pożarze w latach 70 . XX w., kiedy to wprowadzono w nim pewne upraszczające zmiany. Ale dopiero trwający od $2014 \mathrm{r}$. jego kompleksowy remont - którego efektem ma być powstanie dużego biurowca z częścią usługowo-handlową o nazwie Cedet - zasadniczo zagroził integralności pierwotnego dzieła. Stołeczny konserwator zabytków zgodził się bowiem na niemal całkowite wyburzenie starego budynku, za co był zresztą wielokrotnie i publicznie mocno krytykowany. Teoretycznie, zgodnie z planami, jednej z dwóch części CDT 
miał być przywrócony oryginalny wygląd, natomiast druga zostanie zastąpiona całkiem nową, większą konstrukcją - nowym skrzydłem u zbiegu Brackiej i Kruczej. Zdaniem krytyków, już sam ten fakt narusza jedną z kluczowych idei modernistycznej architektury, która odnosi się także do CDT. W konwencji tej budynki projektowano mianowicie najczęściej jako wolno stojące, które niczym architektoniczne rzeźby miały być podziwiane ze wszystkich stron.

W praktyce, według stanu rzeczy na początek 2017 r., można powiedzieć, że całe to remontowe przedsięwzięcie nie jest w istocie zapowiadaną rewitalizacją, lecz radykalną rozbiórką i tylko bardzo częściową rekonstrukcją. Z kompletnie wybebeszonego starego, oryginalnego gmachu głównego przy Al. Jerozolimskich, póki co ocalał jedynie niewielki kawałek klatki schodowej i cienki plaster żelbetowej konstrukcji, ale nie ma pewności, czy i on przetrwa ze względu na zły stan techniczny, jaki mają diagnozować niektóre ekspertyzy. Cała inwestycja ma być zakończona pod koniec $2017 \mathrm{r}^{17}$.

Architekci ze znanej pracowni JEMS zgodnie nazywają tę przebudowę skandalem, a jeden z nich, Maciej Miłobędzki, tłumaczy to w następujący sposób: „Wartością Smyka była jego forma - zestawienie lekkiej przeszkolonej struktury od Al. Jerozolimskich i znacznie mniej ażurowej z tyłu, którą całkowicie zburzono. Ważne były detale: wygięty dach z tarasem, eliptyczne kominy"18. A tak o tym akcie dewastacji obiektu wpisanego do rejestru zabytków emocjonalnie, $\mathrm{z}$ emfazą i nostalgią mówił historyk sztuki i architektury prof. Waldemar Baraniewski: „Ten budynek był w latach 50. symbolem polskich aspiracji do bycia na Zachodzie, do wolności. Jego przeszklone elewacje jasno świeciły w stalinowskiej nocy. Zniszczenie go jest haniebne"19.

- Reinkarnacja albo status quo ante - przypadek Rotundy PKO

Dużo bardziej udanym projektem modernizacyjnym wydaje się rozbiórka i powrót do pierwowzoru Rotundy PKO u zbiegu Al. Jerozolimskich i ul. Marszałkowskiej - ikonicznego okrąglaka, który nazywany jest niekiedy czapką generalską, bo rysunek krawędzi jego dachu przywodzi skojarzenie z generalskim wężykiem na otoku (innym znów przypomina plisowaną spódniczkę). Oddano ją do użytku w 1966 r. jako element większej całości urbanistycznej nazwanej Ścianą Wschodnią. Oprócz pawilonu bankowego na kompleks ów złożyły się w latach 60. XX w. trzy Domy Towarowe Centrum (Wars, Sawa i Junior), trzy towarzyszące im wysokościowce

17 M. Wojtczuk, Cedet w rok wyskoczy z ziemi, „Gazeta Wyborcza”, 18.08.2016.

18 Wypowiedź, „Gazeta Wyborcza”, 15.04.2016.

19 Wypowiedź, „Gazeta Wyborcza”, 23.10.2015. 
mieszkalne oraz biurowiec Universalu na tyłach Rotundy, uzupełnione następnie o super panoramiczne kino Relax (z największym w mieście 19-metrowym ekranem) oraz dom towarowy Sezam. Wszystko to zostało razem spięte, niczym kręgosłupem, pasażem, przy którym zlokalizowano jeszcze kilka sklepów, barów i kawiarni.

Był to wzorcowy przykład socmodernistycznej architektury, wysoko ceniony nie tylko w Polsce. Dla warszawiaków przytłoczonych w latach 50. architekturą socrealistyczną, a zwłaszcza skalą i stylem pobliskiego, kapiącego od ozdób Pałacu Kultury, był to prawdziwy „kawałek wielkiego świata”, powiew Zachodu - a właściwie Północy, bo w dużej mierze w grę wchodziło tu inspirowanie się czy wręcz naśladowanie wzorów skandynawskich. Nie było bez znaczenia, że w centrum Sztokholmu powstał wcześniej podobny do Ściany Wschodniej kompleks Sergelgatan, a w Rotterdamie także deptak Lijnbaan, choć w opinii wielu - nie tylko polskich - krytyków architektury oba pierwowzory nie dorównywały urodą późniejszemu w czasie warszawskiemu dziełu. Nieprzypadkowo aktualne studium zagospodarowania Warszawy, a więc swego rodzaju przestrzenna konstytucja miasta, nadało mu rangę dobra kultury współczesnej i jednego z 16 najcenniejszych układów urbanistycznych w stolicy ${ }^{20}$.

Nie zapobiegło to jednak temu, że w wolnej Polsce obwieszono budynki Ściany Wschodniej gigantycznymi banerami reklamowymi, Domy Centrum nadbudowano o kondygnację, zrewitalizowano z bardzo wątpliwym skutkiem Pasaż Wiecha, radykalnie przebudowano dawny bar Zodiak, wyburzono Sezam (zwalniając przestrzeń dla nowego 10-piętrowca, na którego elewacji ma się jednak pojawić odrestaurowany neon „Sezam”), a w 2017 r. także biurowiec Universalu, by postawić na jego miejscu znacznie wyższy, bo prawie 100-metrowy przeszklony drapacz chmur. Po drugiej stronie ronda Dmowskiego niby przetrwał modernistyczny pawilon Cepelii, ale też został brutalnie oszpecony reklamowymi płachtami, tracąc w ten sposób swą urodę i godność. Zagrożony został w końcu fizyczny byt Rotundy PKO, gdyż w opinii jej właściciela (banku PKO BP), popartej inżynierskimi ekspertyzami, ta przestarzała konstrukcja ujawniała po latach rosnącą liczbę wad, generowała coraz więcej niedogodności i kosztów. Podczas deszczu od dawna przeciekał dach, zimą przeszklony pawilon ujawniał słabą energooszczędność (ciepło uciekało zeń zresztą nie tylko przez nieszczelne wielkie okna), zaś latem zamienia się w duszną szklarnię o prawie subtropikalnym klimacie. Kierując się tymi i innymi podobnymi motywami, zdecydowano więc o rozbiórce starego budynku i postawieniu w jego miejsce nowego, przy użyciu nowoczesnych technologii i materiałów.

Pojawiły się wszakże kontrowersje wokół zakresu, charakteru i spodziewanego finalnego efektu rekonstrukcji. Pierwotny, zaakceptowany przez bank projekt z $2010 \mathrm{r}$.

20 M. Wojtczuk, Jak mogliśmy zapomnieć o Ścianie Wschodniej?, „Gazeta Wyborcza”, 31.03.2017. 
przewidywał wzniesienie pawilonu o podobnych gabarytach, ale o innym kształcie, co wzbudziło jednak powszechne niezadowolenie, wręcz oburzenie i protesty. $\mathrm{W}$ rezultacie wycofano się z tego planu, zorganizowano panele eksperckie i rozległe, masowe konsultacje społeczne. Drugi, ostatecznie przyjęty do realizacji, a wybrany w 2013 r. we wzorowo zorganizowanym międzynarodowym konkursie Changing The Face projekt przewiduje powrót do oryginalnego kształtu Rotundy. A warto przypomnieć, że forma ta została już znacząco naruszona i architektonicznie zubożona w wyniku odbudowy po tragicznej katastrofie wywołanej wybuchem gazu w podziemnych instalacjach w 1979 r. (zginęło wówczas 49 osób). Z dużą pieczołowitością, wiernie ma być przywrócona m.in. przezroczysta elewacja, zapewniająca pawilonowi oryginalną lekkość, otwartość i transparentność, odebrane mu przez zainstalowane po katastrofie nieprzezroczyste, refleksyjne tafle szkła ${ }^{21}$.

Nie słabną wszakże dyskusje i spory wokół tej rekonstrukcji. Towarzystwo Opieki nad Zabytkami w 2016 r. krytycznie uznało, że zaplanowany nowy budynek „nie prezentuje żadnego podobieństwa z jego wybitnym pierwowzorem", co wydaje się opinią odbiegającą od prawdy. Niemniej jednak część komentatorów stawia pytanie, czy całkowicie nowa Rotunda, powtarzająca starą formę, ubrana jedynie w historyczny kostium i udająca autentyk, wciąż będzie nowatorskim dziełem modernizmu lat 60 . Pozostają wątpliwości, czy będąc - jak pisze Tomasz Urzykowski - „przykładem "modernizacji« wartościowych budynków poprzez rozbiórkę i budowę od podstaw”, przypadek ten nie świadczy czasem o sprowadzaniu ochrony zabytków do karykatury ${ }^{22}$.Zabytek nie jest przecież tylko formą, lecz także pewną oryginalną substancją materialną - przypomina się z naciskiem nie bez racji i podstaw. W innych opiniach przewiduje się i podkreśla, że raczej nie będzie ona „mauzoleum modernizmu, tylko Rotundą XXI w., ale w duchu tej sprzed wybuchu gazu”23. Ma mieć wszystkie zalety starego, oryginalnego pawilonu, ale bez jego funkcjonalnych wad. Czy w takiej sytuacji można jednak jeszcze mówić o historycznej ciągłości budynku?

W marcu 2017 r. stołeczny konserwator zabytków nakazał wstrzymać prace rozbiórkowe, gdy odsłonięty po zdemontowaniu elewacji i poszycia dachu stalowy szkielet, misternie utkany z dźwigarów, słupów obwodowych i kratownicy dachu, okazał się co najmniej w części oryginalny (a nie podmieniony w 1979 r.) i w całkiem dobrym stanie ${ }^{24}$. Konserwator opowiedział się za zachowaniem tej przypominającej

21 M. Wojtczuk, Rotunde zbuduja od nowa, „Gazeta Wyborcza”, 16.09.2016.

${ }_{22}$ T. Urzykowski, Rozbiórka Rotundy, czyli dysharmonia Ściany Wschodniej, „Gazeta Wyborcza”, 14.03.2017.

23 D. Bartoszewicz, W koło Rotunda, „Gazeta Wyborcza”, 27-28.02.2016.

24 Eksperci stwierdzili, że wiszący dach pawilonu podczas wybuchu gazu zadziałał jak parasol: uniósł się, a następnie powrócił do pierwotnego stanu. Co tylko potwierdza, że Rotunda była produktem wybitnej, unikatowej myśli inżynierskiej, tym bardziej wartym zachowania jako świadectwo minionego 
delikatną pajęczynę pozostałości autentycznej konstrukcji jako obiektu znajdującego się w gminnej ewidencji zabytków. Z kolei wojewódzki konserwator nie podzielił tej opinii, dowodząc, że przyjęty projekt jego odtworzenia od podstaw jest w pełni racjonalnym i odpowiedzialnym rozwiązaniem ${ }^{25}$. Dodatkowe ekspertyzy pokazały, że planowana budowa podziemnej kondygnacji pawilonu nie jest możliwa bez zasadniczego demontażu całej konstrukcji. Zdecydowano jednak kompromisowo, że odbywać się to będzie dalej inną technologią i pod nadzorem specjalnego zespołu przedstawicieli stołecznego konserwatora i inwestora, a niektóre elementy zostaną zdemontowane z jak najmniejszą ingerencją i następnie wykorzystane np. jako artefakty ${ }^{26}$. Wcześniej zakładano, że szkielet będzie pocięty palnikami na drobne kawałki i wywieziony na złomowisko.

Przewiduje się, że rekonstrukcja Rotundy ma być ukończona na wiosnę $2019 \mathrm{r}$. Jej pierwsze piętro ma być dostępne także po godzinach funkcjonowania banku i zostanie przeznaczone na funkcje publiczne (np. sala konferencyjna, wystawowa lub restauracja, tego jeszcze nie przesądzono), co jest nowością w stosunku do jej obecnej roli użytkowej. Szerokie amfiteatralne schody poprowadzą do podziemnej kondygnacji budynku, wokół niego powstanie zadbany, wyłożony granitowymi płytami plac z kilkoma drzewami. A nad nim rozpięta zostanie konstrukcja z kevlarowych cięgien dźwigających oświetlenie. „To nasz hołd dla ażurowych pergoli, które kiedyś istniały w pasażu Wiecha" - deklaruje współautor projektu Bartłomiej Gowin ${ }^{27}$.

Można oczekiwać, że Rotunda PKO znów, jak kiedyś, będzie świecić w nocy niczym symboliczna mega latarnia miejska, a nie służyć - jak to się działo ostatnio - za wielki wieszak na nie zawsze estetyczne reklamy. I znów będzie odgrywać rolę swoistej kropki nad „i” w całym założeniu Ściany Wschodniej. Pod warunkiem wszakże, że w takiej czy innej formie ten najważniejszy, zdaniem wielu ekspertów, układ urbanistyczny stolicy okresu PRL w ogóle przetrwa, co po kontrowersyjnej renowacji pasażu, wyburzeniu biurowca Universalu, magazynu Sezam i planowanej rozbiórce kina Relax ${ }^{28}$ (sprzedanego wcześniej przez spółkę Max-Film sieci delikatesów Alma) nie wydaje się całkiem przesądzone.

czasu. W tym świetle podpisanie w 2015 r. przez ówczesnego stołecznego konserwatora zabytków zgody na całkowitą rozbiórkę pawilonu jako konstrukcji wtórnej, a nie oryginalnej, można uznać nie tylko za błąd, ale i za niedopełnienie obowiązków służbowych, co może podlegać odpowiedzialności karnej (M. Wojtczuk, Rotunda nie będzie zabytkiem. Wielka szkoda, „Gazeta Wyborcza”, 4.04.2017).

25 T. Urzykowski, Stop rozbieraniu Rotundy, „Gazeta Wyborcza”, 17.03.2017.

26 T. Urzykowski, Rozbiórka Rotundy zaczęła się od nowa, „Gazeta Wyborcza”, 6.04.2017.

27 Cyt. za: M. Wojtczuk, Rotunda zniknie. Na dwa lata, „Gazeta Wyborcza”, 23.11.2016.

28 Niektórzy pocieszają się, że projekt planu zagospodarowania rejonu Ściany Wschodniej wprawdzie zezwala na budowę w jego miejsce nowego 28 -metrowego budynku, ale nakazuje zarazem zachowanie oryginalnego neonu Relax oraz okładziny elewacji z odpadów porcelitowych, M. Wojtczuk, Spięcie w sprawie Relaksu, „Gazeta Wyborcza”, 29.03.2017. 
- Translokacja z metamorfozą - przypadek pawilonu Emilia

Casus kontrowersyjnego demontażu i przeprowadzki budynku, z pewną modernizacyjną korektą przy jego odtworzeniu, zilustrować mogą losy kultowego dawnego Domu Meblowego Emilia. Postawiony w 1970 r. przy ul. Emilii Plater nieopodal PKiN, obiekt ów od początku czarował lekkością i finezją, podobnie jak wspomniane wcześniej wyburzone pawilony handlowe ${ }^{29}$. Z zewnątrz uwagę przechodniów szczególnie przykuwał oryginalny dach, wygięty w figlarny, zawadiacki wężyk. Z kolei wewnątrz ten, zdawałoby się, płaski pawilon zaskakiwał klientów rozległą przestrzenią, wysoką na trzy kondygnacje monumentalną halą, w której rozgrywał się magiczny spektakl schodów, kolumn i okien. Oglądana z zewnątrz Emilia wydawała się dużo mniejsza niż była w środku.

Jednak z biegiem lat pawilon ów podupadał, niszczał i marniał - już mało kto zauważał, że jest awangardowy, lekki i przejrzysty jak designerska witryna, znikał blask szyb i aluminiowych profili. Przybywało zwolenników opinii, zwłaszcza w ostatniej dekadzie XX w., że to „koszmarne pudło, PRL-owski barak, szara od brudu stodoła" ${ }^{\prime 30}$. Pewną próbę reanimacji, przywrócenia do życia i dawnej formy obiekt przeżył w latach 2012-2016, gdy po okresie zaniedbań i nieużytkowania stał się tymczasową siedzibą Muzeum Sztuki Nowoczesnej. Starano się wówczas przywrócić Emilii jej stary wygląd, eliminując zbędne estetycznie narośle (w rodzaju podwieszonych sufitów, wykładziny podłogowej typu sztuczna trawa czy pastelowych okładzin na filarach) i dostosowując wnętrze do celów wystawowych poprzez usunięcie m.in. różnych płyt gipsowych zasłaniających widok na ekspozycje także z zewnątrz.

Prawdziwe, egzystencjalne wyzwanie pojawiło się wreszcie dla Emilii wtedy, gdy firma deweloperska Griffin Real Estate, która w 2012 r. zakupiła ją wraz z działką od skarbu państwa, zaplanowała postawienie w jej miejsce strzelistego, sięgającego prawie $200 \mathrm{~m}$ drapacza chmur. Sytuację skomplikował fakt, że już po uzyskaniu przez inwestora pozwolenia na rozbiórkę, mazowiecka konserwator zasugerowała połączenie pawilonu, jako swoistej wartości dodanej, z przyszłym wieżowcem i wszczęła w lutym 2016 r. procedurę wpisania go do rejestru zabytków ${ }^{31}$. Pozytywna decyzja w tej sprawie zapadła w grudniu tegoż roku, gdy obiekt był już częściowo rozebrany, ale Ministerstwo Kultury uchyliło ją dwa miesiące później, dopatrując się w owym postanowieniu licznych uchybień.

29 Gorzej było z dostępnością towarów przeznaczonych do sprzedaży. „Szkoda, że meble można tu było kupić tylko przez kilka dni po otwarciu” - pisał ką́liwie w marcu 1970 r. tygodnik „Stolica”, zob. Emilia. Meble, muzeum, modernizm, Warszawa 2016.

30 M. Wojtczuk, Dorzynanie białego nosorożca, „Gazeta Wyborcza”, 21.07.2015.

31 T. Urzykowski, Spór o Emilię skończy się w sądzie?, „Gazeta Wyborcza”, 3.03.2016. 
Jednocześnie w tym samym 2016 roku, z inicjatywy stołecznego konserwatora zabytków, zrodził się pomysł uratowania Emilii poprzez przeniesienie jej, a właściwie jej fragmentów, w inne, choć nieodległe miejsce, na skraj parku Świętokrzyskiego pod sam PKiN, na osi głównego wejścia do Pałacu Młodzieży ${ }^{32}$. Przeprowadzka ma objąć dach i ważniejsze części wystroju wnętrza, takie jak balustrady, poręcze i stopnie schodów, mozaikowe posadzki z ceramicznych płytek i lastriko, oryginalne okładziny ścian, filarów i słupów. Koncepcja ocalenia pawilonu - oprócz złożenia na powrót pociętych wcześniej na kawałki starych elementów - przewiduje postawienie w istocie nowej konstrukcji z żelbetu, energooszczędnych szklanych elewacji, instalacji i podziemia. Cała operacja z pogranicza inżynierii i sztuki ma kosztować prawie $25 \mathrm{mln}$ zł, z czego ratusz pokryje połowę, a więc mniej więcej tyle, ile w $2015 \mathrm{r}$. przeznaczył na dotacje do remontu zabytków w całej Warszawie. Przy czym, co warto zauważyć, wykonanie wiernej kopii całego pawilonu, w tym dachu, byłoby o wiele tańsze i prostsze.

Czy można ocenić ten pomysł jako fortunny, sensowny, biorąc pod uwagę nie tylko jego poważne koszty finansowe? Część komentatorów i historyków sztuki potraktowała ideę przeprowadzki jak jedyną szansę na bodaj częściowe przetrwanie pawilonu, skoro niemożliwe stało się pozostawienie go w dotychczasowej formie na starym miejscu. Akt przenosin autentycznej substancji, nawet tylko oryginalnego dachu, miałby symboliczne znaczenie. $Z$ prawnego punktu widzenia translokacja zabytkowych budowli jest ustawowo dopuszczana. Współprojektantka obiektu Hanna Lewicka dostrzega pewien dodatkowy walor tej operacji: projektowany do większej przestrzeni i wysunięty przed inne budynki, teraz nazbyt wciśnięty w nową zabudowę i przez nią przyduszony, w nowym miejscu pawilon odzyskałby mniej zagęszczone, bliższe pierwotnemu otoczenie ${ }^{33}$.

Inni uznają, że odtworzony w innej lokalizacji, w dużej części z nowych materiałów, byłby już tylko rodzajem makiety, pozbawioną duszy wydmuszką w rodzaju zrekonstruowanego Pałacu Jabłonowskich przy pl. Teatralnym ${ }^{34}$. W żadnym razie nie będzie to już ta sama Emilia. Wielu architektów i ekspertów podkreśla, że oryginalną, wyjątkową wartością Emilii były nie tyle jej szklane elewacje i pofałdowany dach $\mathrm{z}$ trapezowymi załamaniami (bo takie rozwiązania nie są na świecie zupełną rzadkością), lecz przede wszystkim cały mini układ urbanistyczny towarzyszący pawilonowi, w tym przeszkolony łącznik z blokiem mieszkalnym, patio z pasażem i drzewami, a dziś także ciekawy kontrast między niskim budynkiem a wysokimi

32 T. Urzykowski, Emilia przed Pałacem?, „Gazeta Wyborcza”, 27-28.02.2016.

33 Rozmowa, „Gazeta Wyborcza”, 23.09.2016.

34 D. Bartoszewicz, Emilia nie spotka buldożera, „Gazeta Wyborcza”, 14-15.05.2016. 
nowoczesnymi biurowcami, hotelem Intercontinental i apartamentowcem w najbliższej okolicy. Deklaracje inwestora o zachowaniu starego pasażu nieopodal przyziemia sąsiedniego bloku nie zadawalają jego adwersarzy i sceptyków.

Jak argumentował w obronie starej lokalizacji Emilii krytyk architektury Grzegorz Piątek: „Choć handlowano w niej meblami, to ona sama nie jest szklaną etażerką, która można przesuwać $\mathrm{z}$ kąta w kąt". Biorąc ponadto pod uwagę, że w nowym miejscu miałby w niej znaleźć siedzibę ogród zimowy (z powierzchniami ekspozycyjnymi), zdaniem Piątka „nienaturalna wydaje się próba pogodzenia starej formy i substancji z nową lokalizacją i funkcją" ${ }^{35}$. Podobnie sceptycznie wypowiada się na ten temat architekt Marlena Happach, kwestionująca utrzymanie architektonicznej wartości Emilii po wycięciu jej, wyrwaniu z obecnego kontekstu przestrzennego ${ }^{36}$. Wtóruje tym głosom wielu aktywistów miejskich, m.in. ze Stowarzyszenia „Miasto Jest Nasze”37.

- Twórczy dialog z przeszłością - siedziba Fundacji Galerii Foksal

Ciekawym przykładem eksperymentu modernizacyjnego, który także wywołał ożywioną dyskusję w środowisku polskich architektów, jest zakończona w 2015 r. radykalna przebudowa siedziby Fundacji Galerii Foksal przy ul. Górskiego na tyłach Nowego Światu. Zaprojektował ją szwajcarski architekt Roger Diener, jak wskazywano - w „dialogu z przeszłością”, zresztą w porozumieniu i przy akceptacji pierwotnego projektanta budynku - Leszka Klajnerta.

Z poprzedniego obiektu plomby - lekkiego, trzypiętrowego pawilonu z kurtynowymi szklanymi ścianami - pozostała właściwie tylko szkieletowa konstrukcja, na której zainstalowano teraz 12 szarych, betonowych płyt, które klarownie wskazują na wewnętrzne podziały budynku. Nawiązują one do dobrze znanych prefabrykatów, z których wznoszono w PRL tysiące jednakowych modernistycznych bloków mieszkalnych. Ciężka nowa fasada, choć opatrzona kilkoma wielkimi panoramicznymi oknami, jest - jak przekonuje Springer - swego rodzaju twórczą reinterpretacją dużo bardziej przejrzystej, starej, rozebranej już, elewacji ${ }^{38}$.

W świetle ortodoksyjnej, pryncypialnej (czy też skrajnie konserwatywnej) doktryny konserwatorskiej można by pewnie uznać tę modernizację za nieakceptowalną, godną potępienia profanację, ale $\mathrm{z}$ drugiej strony można też $\mathrm{w}$ zrealizowanym projekcie zobaczyć nową, XXI-wieczną architekturę, jak pisze Piątek - „nieodwołującą się do

35 G. Piątek, Operacja Emilia, „Gazeta Wyborcza”, 4.03.2016.

36 Rozmowa, „Gazeta Wyborcza”, 26.02.2016.

37 T. Urzykowski, Nowa wojna o Emilię, „Gazeta Wyborcza”, 3.01.2017; T. Urzykowski, Emilia zabytkiem, ale wpisana niedbale, „Gazeta Wyborcza”, 11.01.2017.

38 F. Springer, Księga zachwytów, Warszawa 2016, s. 196. 
pierwotnej formy budynku, ale estetycznie i ideowo zakorzenioną w powojennym modernizmie". Przypadek tej dobrze przemyślanej przebudowy pokazuje, że można stworzyć nową kreację, nowe dzieło, ale zgodnie z dawną konwencją, tradycyjnym duchem. Autentyczny, ale typowy i wysłużony detal nie zawsze zasługuje na konserwację, często „wystarczy tylko zachować najważniejsze cechy budynku - jego gabaryt, kształt, wielkość okien, podziały elewacji, geometrię dachu"39.

Odchodząc już od podlegających w ostatnich latach przemianom dzieł warszawskiego modernizmu, można by wskazać wiele innych, znamiennych i często głośnych, bo kontrowersyjnych przypadków przekształceń, jakim ulegały w tym samym czasie dobrze znane i często uczęszczane fragmenty stołecznej przestrzeni publicznej. Wymieńmy tu, tytułem przykładu, niedawną rewitalizację Krakowskiego Przedmieścia, przemiany zachodzące w zachodniej części Śródmieścia, na zabudowywanym wieżowcami pograniczu z Wolą, czy też bardziej indywidualne przypadki, jak dyskusyjna rekonstrukcja zabytkowej Hali Koszyki. To już jednak temat na inne rozważania i osobny artykuł.

\section{Bibliografia}

Anioł W., Kształtowanie przestrzeni miejskiej jak mikrokosmos polityki publicznej. Przypadek Warszawy, „Studia z Polityki Publicznej” 2016, nr 2.

Anioł W., Pułapka ekonomizmu. U źródeł dominacji neoliberalnej narracji modernizacyjnej w Polsce, „Przegląd Socjologiczny” 2015, t. LXIV, nr 2.

Anioł W., Szlak Norden. Modernizacja po skandynawsku, Warszawa 2013.

Anioł W., Wokót urynkowienia usług społecznych, „Polityka Społeczna” 2016, nr 1.

AR/PS. Architektura Arseniusza Romanowicza i Piotra Szymaniaka, red. G. Piątek, Warszawa 2012. Brzostek B., Za progiem. Codzienność w przestrzeni publicznej Warszawy 1955-1970, Warszawa 2007.

Emilia. Meble, muzeum, modernizm, Warszawa 2016.

Le Corbusier, Urbanistyka, Warszawa 2015.

Le Corbusier, $W$ stronę architektury, Warszawa 2012.

Miłobędzki A., Architektura ziem polskich - rozdział europejskiego dziedzictwa, Kraków 1994. Spór o odbudowę Warszawy. Od gruzów do reprywatyzacji, red. T. Fudala, Warszawa 2017.

Springer F., Księga zachwytów, Warszawa 2016.

Springer F., Miasto Archipelag. Polska mniejszych miast, Kraków 2016.

Springer F., Źle urodzone. Reportaże o architekturze PRL, Kraków 2012.

39 G. Piątek, Nowiutkie zabytki, „Gazeta Wyborcza”, 2.04.2015. 
Streeck W., Thelen K., Introduction: Institutional Change in Advanced Political Economies, w: Beyond Continuity: Institutional Change in Advanced Political Economies, red. W. Streeck, K. Thelen, Oxford-New York 2005.

Wantuch-Matla D., Przestrzeń publiczna 2.0. Miasto u progu XXI wieku, Łódź 2016. 